University of Nebraska - Lincoln

DigitalCommons@University of Nebraska - Lincoln

Faculty Publications from the Harold W. Manter Laboratory of Parasitology

4-1978

\title{
The Opossum (Didelphis virginiana) as a Host for Sarcocystis debonei from Cowbirds (Molothrus ater) and Grackles (Cassidix mexicanus, Quiscalus quiscula)
}

Donald Duszynski

University of New Mexico, eimeria@unm.edu

Edith D. Box

University of Texas Medical Branch

Follow this and additional works at: https://digitalcommons.unl.edu/parasitologyfacpubs

Part of the Parasitology Commons

Duszynski, Donald and Box, Edith D., "The Opossum (Didelphis virginiana) as a Host for Sarcocystis debonei from Cowbirds (Molothrus ater) and Grackles (Cassidix mexicanus, Quiscalus quiscula)" (1978). Faculty Publications from the Harold W. Manter Laboratory of Parasitology. 129.

https://digitalcommons.unl.edu/parasitologyfacpubs/129

This Article is brought to you for free and open access by the Parasitology, Harold W. Manter Laboratory of at DigitalCommons@University of Nebraska - Lincoln. It has been accepted for inclusion in Faculty Publications from the Harold W. Manter Laboratory of Parasitology by an authorized administrator of DigitalCommons@University of Nebraska - Lincoln. 


\title{
THE OPOSSUM (DIDELPHIS VIRGINIANA) AS A HOST FOR SARCOCYSTIS DEBONEI FROM COWBIRDS (MOLOTHRUS ATER) AND GRACKLES (CASSIDIX MEXICANUS, QUISCALUS QUISCULA)
}

\begin{abstract}
Donald W. Duszynski* and Edith D. Box $\dagger$
ABSTRACT: Sarcocystis-infected muscles from ducks, cowbirds, and grackles were fed to cats, opossums, rats, and a dog. Only the opossum (Didelphis virginiana) was a suitable definitive host. All opossums that were fed Sarcocystis-infected cowbirds (Molothrus ater) and grackles (Cassidix mexicanus and Quiscalus quiscula) passed sporocysts in their feces. Opossums that ate the cowbirds had prepatent periods of 5 and 10 days and remained patent for at least 105 days. Opossums that ate the grackles became patent on day 10 after the infective meal and remained patent for over 90 (Quiscalus) and 105 (Cassidix) days. A single opossum fed infected muscle from a pintail duck (Anas acuta) passed sporocysts in the feces from days 13 through 18 after infection. No sporocysts were passed by opossums fed infected muscle from the green-winged teal (Anas carolinensis) and shoveller (Spatula clypeata). Sporocysts of duck, cowbird, and grackle origin were structurally similar. Mean dimensions of sporocysts were: duck-origin, 11.2 by $8.2 \mu \mathrm{m}$; cowbird-origin, 11.4 by $7.8 \mu \mathrm{m}$; Cassidix-origin, 11.2 by $7.8 \mu \mathrm{m}$; and Quiscalus-origin, 11.6 by $7.7 \mu \mathrm{m}$. We designate the sporocysts of cowbird and grackle origin as Sarcocystis debonei Vogelsang, 1929 (Syn. Isospora boughtoni Volk, 1938).
\end{abstract}

Sarcocystis species are ubiquitous parasites with an obligatory two-host cycle. The forms that parasitize muscles of mammals (cattle, sheep, pigs, rats, mice, horses, and deer) have recently been shown to be acquired by ingestion of isosporan-like sporocysts shed by a host which had previously ingested infected muscle (for reviews, see Dubey, 1976; Kalyakin and Zasukhin, 1975; Levine, 1977). Macroscopic cysts of Sarcocystis are commonly seen in muscles of certain avian species (e.g., grackles and puddle ducks), but the definitive hosts for these forms, i.e., the hosts which discharge the infective sporocysts in their feces, are presently unknown.

Results reported here show that the opossum (Didelphis virginiana) is a good host for the Sarcocystis of three species of icterid birds; it is also a possible host for one species of duck Sarcocystis, although apparently not the major one. Cats, rats, and a dog fed avian tissues infected with Sarcocystis failed to discharge sporocysts in their feces.

\section{MATERIALS AND METHODS}

\section{Experimental definitive hosts}

Opossums were purchased from the University of Texas Science Park, Bastrop, Texas. They had

Received for publication 27 May 1977.

* Department of Biology, The University of New Mexico, Albuquerque, New Mexico 87131.

$\dagger$ Department of Microbiology, The University of Texas Medical Branch, Galveston, Texas 77550. been trapped in the vicinity of Bastrop and were routinely held a minimum of 3 weeks before being sold for experimental use. During that time they were fed only dry commercial dog chow. After we received them, the opossums were kept in the University Animal Care Center, Galveston, Texas or in animal quarters of the University of Texas Medical School, Houston, Texas and were fed dry commercial dog chow.

The cats were adult strays obtained from the University Animal Care Center and were maintained there as part of a study on Brugia malayi infections. One stray dog and five adult SpragueDawley rats were also maintained at the University Animal Care Center.

\section{Avian hosts}

Three species of ducks with muscle cysts were obtained during duck-hunting season from various donors, Anas acuta (pintail), Anas carolinensis (green-winged teal), and Spatula clypeata (shoveller). Infected breast and thigh muscles were removed and refrigerated from 1 to 15 days before being fed to animals. All were shot in Galveston County, Texas, except for the pintail and one green-winged teal, which were from Hudspeth County (near El Paso, Texas).

Cowbirds (Molothrus ater) and grackles (Quiscalus quiscula and Cassidix mexicanus) were collected within or near the city limits of Houston by mist-net or live trap. All birds were skinned and examined for tissue cysts with a lighted magnifying lens. Particular attention was paid to tissues of the breast, thigh, calf, and back muscles (for incidence of infection, see Box and Duszynski, 1977). From one to seven infected, skinned (but not eviscerated) birds were fed whole to cats and opossums. Rats were fed muscle pieces containing cysts. All icterid birds had been dead and refrigerated from 2 to 5 days when fed to experimental hosts. 
TABLE I. Predator-prey combinations for Sarcocystis transmission experiments $(-=1$ animal negative for sporocysts; $+=1$ animal positive for sporocysts; $N D=$ combination not tried).

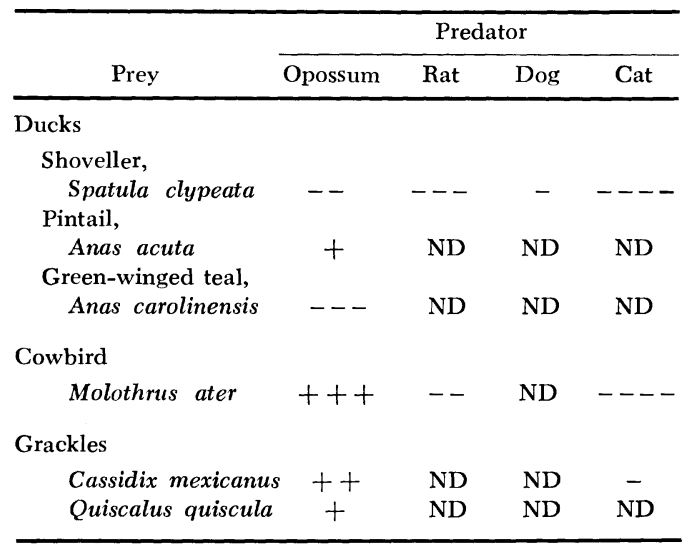

\section{Fecal examination}

All hosts tested as experimental definitive hosts were caged individually. The feces of each animal were examined by sugar flotation at least twice prior to feeding them infected tissues to check for extraneous coccidian infections. Feces were also examined daily or every other day beginning 3 to 5 days after an animal was fed infected meat, and continuing for 28 days in hosts that remained negative and for at least 100 days for hosts which passed sporocysts.

\section{Sporocyst measurements}

Sporocysts recovered from opossums were stored in $2 \%$ aqueous $(\mathrm{w} / \mathrm{v})$ potassium dichromate $\left(\mathrm{K}_{2} \mathrm{Cr}_{2} \mathrm{O}_{7}\right)$ solution at 4 to $5 \mathrm{C}$. They were concentrated, washed, and measured at $1,000 \times$ as described earlier (Duszynski and Marquardt, 1969). All measurements are in micrometers unless otherwise stated. Mean values were compared using Student's $t$-test; differences were considered significant when probability values were $<0.01$.

\section{RESULTS}

\section{Transmission experiments (Table $\mathrm{I}$ )}

The feces from nine cats, five rats, and one dog remained negative for sporocysts for at least 28 days after they were fed Sarcocystiscontaining muscle from ducks, cowbirds, or grackles.

One opossum discharged sporocysts in its feces 13 through 18 days after ingesting infected breast muscle from a pintail duck collected 15 days previously. However, heavily infected teal and shoveller muscle was fed to five opossums with negative results.
Each of six opossums fed skinned, whole infected icterid birds became infected. One opossum was killed $\sim 38 \mathrm{hr}$ after eating three infected cowbirds to collect intestinal tissue for histological examination of early endogenous development. Fecal examinations of this animal had been negative for coccidia for 30 days prior to its eating the infected cowbirds. Tissue impression smears and sections showed developing gamonts throughout the length of the small intestine; these gamonts were presumed to be stages of Sarcocystis development. A second opossum became patent 10 days after eating six infected cowbirds and was killed 2 days later to collect tissues for later study. A third opossum which ate seven infected cowbirds began passing sporocysts 5 days later and continued to pass large numbers of them daily for at least 105 days. Our fourth and fifth opossums were fed one and two grackles (Cassidix), respectively, and both began to discharge sporocysts 10 days later; one passed sporocysts for 20 consecutive days until it was killed for endogenous stages, and the other continued to pass sporocysts for at least 105 days. The opossum fed one grackle of the genus Quiscalus became patent 10 days later, and continued to pass sporocysts daily for at least 90 days.

\section{Sporocysts (Table II)}

Sporocysts of cowbird $(\mathrm{N}=25)$ and grackle ( $N=25$, each species $)$ origin differed significantly in size or length/width ratio from those of duck origin $(N=25)$ in six of nine possible comparisons; those of cowbird origin differed significantly from those of grackle origin in two of six possible comparisons (Table II). Residua in sporocysts of bird origin were highly variable and appeared either compact or as scattered granules.

We designate the sporocysts of cowbird and grackle origin as Sarcocystis debonei Vogelsang 1929 (Syn. Isospora boughtoni Volk 1938) based on these criteria: (1) Vogelsang (1929) was the first to name a sarcocystid from cowbirds; thus, his name has priority over all later ones; (2) sporocysts of icterid bird origin are similar in four of six size and shape comparisons (Table II); and (3) the prepatent and patent periods in the opossum are similar regardless of which icterid bird form is ingested. 
TABLE II. Mean dimensions (range) of sporocysts $(N=25)$ recovered from opossums fed Sarcocystis from avian hosts.

\begin{tabular}{|c|c|c|c|}
\hline \multirow{2}{*}{$\begin{array}{l}\text { Muscle } \\
\text { source }\end{array}$} & \multicolumn{2}{|c|}{ Sporocyst } & \multirow[b]{2}{*}{$\mathrm{L} / \mathrm{W}$ ratio } \\
\hline & Length $(\mu \mathrm{m})$ & Width $(\mu \mathrm{m})$ & \\
\hline Anas acuta & $11.2(10-12)$ & $8.2(7-9)$ & $1.37(1.22-1.50)$ \\
\hline Molothrus ater & $11.4(11-12)$ & $7.8(7-8) \ddagger$ & $1.47(1.38-1.57) \S$ \\
\hline Cassidix mexicanus & $11.2(11-12)$ & $7.8(7-8) \ddagger$ & $1.44(1.33-1.57)$ \\
\hline Quiscalus quiscula & $11.6(11-12) * \dagger$ & $7.7(7-8) \S$ & $1.51(1.38-1.71) \S \|$ \\
\hline
\end{tabular}

$* P<0.025$ when compared to Cassidix.

$\dagger P<0.01$ when compared to Anas.

$\$ P<0.005$ when compared to Anas.

$\S P<0.001$ when compared to Anas.

$\| P<0.01$ when compared to Molothrus.

We choose not to name the sporocysts of duck origin at this time for reasons discussed below.

\section{DISCUSSION}

The American opossum was utilized in these studies because it is one of the few animals, other than cats and dogs, listed by Pellérdy (1974) as a host from which sporulated isosporan-like sporocysts have been recovered. These were described and named Isospora boughtoni by Volk (1938). Ernst et al. (1969), in the second report of its occurrence in an opossum, mentioned the presence of feathers of a brown-headed cowbird in the intestinal contents, indicating that birds are part of the diet of this omnivorous animal.

Opossums in our experiments became infected in every case in which they ingested infected cowbirds or grackles and continued passing sporocysts for months. This suggests that they are important definitive hosts for Sarcocystis of these icterid birds. The two grackle species and the brown-headed cowbird are all members of the Family Icteridae, but they belong to different genera, whereas sporocysts of Sarcocystis species of dogs and cats, though varying slightly in size, have been found infective for, at most, a single genus of intermediate host (Levine, 1977). Although all sporocysts discharged by our experimentally infected opossums are within the size range reported for I. boughtoni (Volk, 1938; Ernst et al., 1969), we suspect we are dealing here with at least two species. There is sufficient precedent (Duszynski and Marquardt, 1969) to support the contention that exogenous stages of coccidians that differ in size, as do sporo- cysts from duck and icterid bird origins, are distinct species. We have tentatively designated those sporocysts of cowbird and grackle origin as a single species, $I$. debonei, but confirmation of this view must be dealt with later when cross-transmission studies can be made.

Based upon appearance of muscle cysts, the duck Sarcocystis is not the same species found in icterid birds. Macroscopically, cysts from icterid birds were spindle-shaped and measured up to 0.5 by $9.0 \mathrm{~mm}$, whereas those from ducks were more round, had a rice-grain appearance, and measured up to 1.0 by 5.0 $\mathrm{mm}$. Also, the mean size of Giemsa-stained zoites in dried, ethyl alcohol-fixed smears was 10.9 by 3.2 for the duck form and 6.5 by 2.1 for the icterid bird form.

It is difficult to explain the light and temporary shedding of sporocysts by an opossum after feeding with muscles from a pintail duck when heavily infected teals and shovellers did not infect opossums. Possibly the parasite is evolving in a predator-prey relationship between the opossum and pintail but with another major definitive host sustaining the duck infection. The fact that the pintail had been dead for 15 days before being consumed may have caused the infecting dose to be light, resulting in a shorter patency in the definitive host.

\section{ACKNOWLEDGMENTS}

Special thanks are due Mary Jenevein, Houston Mosquito Control Board, for coordinating our efforts with her field personnel, Leon Pate and William Carter, who mist-netted cowbirds and grackles. We also thank Dr. Norman Weisbrodt, Department of Physiology, Uni- 
versity of Texas Medical School, Houston, for use of the opossum to which we fed a pintail duck; Heidi Good, Department of Biology, Rice University, Houston, who live-trapped cowbirds; Mary Anne McCoy and Randall Gould, Galveston, and Drs. J. Bristol and A. Canaris, Department of Biology, University of Texas El Paso, for supplying the infected ducks; Drs. A. Ewert and W. Bosworth of this department for use of their experimental cats; and Dr. N. D. Levine, University of Illinois, for his helpful review of this manuscript.

\section{LITERATURE CITED}

Box, E., AND D. W. Duszynski. 1977. Survey for Sarcocystis in the brown-headed cowbird (Molothrus ater): A comparison of macroscopic, microscopic and digestion techniques. J Wildl Dis 13: 356-358.

Dubey, J. P. 1976. A review of Sarcocystis of domestic animals and of other coccidia of cats and dogs. J Am Vet Med Assoc 169: 1061-1078.
Duszynski, D. W., and W. C. Marquardt. 1969. Eimeria (Protozoa: Eimeriidae) of the cottontail rabbit, Sylvilagus audubonii, in northeastern Colorado with a description of three new species. J Protozool 16: 128-137.

Ernst, J. V., C. Cooper, and B. Сhobotar. 1969. Isospora boughtoni Volk, 1938 and Isospora sp. (Protozoa: Eimeriidae) from an opossum Didelphis marsupialis. Bull Wildl Dis Assoc 5: 406-409.

Kalyakin, V. N., and D. N. Zasukhin. 1975. Distribution of Sarcocystis (Protozoa: Sporozoa) in vertebrates. Folia Parasitol 22: 289307.

Levine, N. D. 1977. Nomenclature of Sarcocystis in the ox and sheep and of fecal coccidiosis of the dog and cat. J Parasitol 63: $36-51$.

Pellérdy, L. P. 1974. Coccidia and Coccidiosis, 2nd ed. Verlag Paul Parey, Berlin, 959 p.

Vogelsang, E. G. 1929. Beiträge zur Kenntnis der Parasitenfauna Uruguays. Sarkosporidien bei Vögeln. Z Bakt Parasitenkd I Orig 113 : 206-208.

VoLk, J. 1938. Isospora boughtoni n. sp., from the American opposum, Didelphis virginiana. J Parasitol 24: 547-548. 